\title{
The role of steroid hormones in breast cancer stem cells
}

\author{
Bruno M Simões ${ }^{1}$, Denis G Alferez ${ }^{1}$, Sacha J Howell, ${ }^{1,2}$ and Robert B Clarke ${ }^{1}$ \\ 'Breast Biology Group, Breast Cancer Now Research Unit, Institute of Cancer Sciences, University of Manchester, \\ Wilmslow Road, Manchester M20 4BX, UK \\ ${ }^{2}$ Department of Medical Oncology, The Christie NHS Foundation Trust, Wilmslow Road, Manchester M20 4BX, UK
}

Correspondence should be addressed to B M Simões Email

Bruno.Simoes@ics. manchester.ac.uk

\begin{abstract}
Breast cancer stem cells (BCSCs) are potent tumor-initiating cells in breast cancer, the most common cancer among women. BCSCs have been suggested to play a key role in tumor initiation which can lead to disease progression and formation of metastases. Moreover, $\mathrm{BCSCs}$ are thought to be the unit of selection for therapy-resistant clones since they survive conventional treatments, such as chemotherapy, irradiation, and hormonal therapy. The importance of the role of hormones for both normal mammary gland and breast cancer development is well established, but it was not until recently that the effects of hormones on BCSCs have been investigated. This review will discuss recent studies highlighting how ovarian steroid hormones estrogen and progesterone, as well as therapies against them, can regulate $\mathrm{BCSC}$ activity.
\end{abstract}

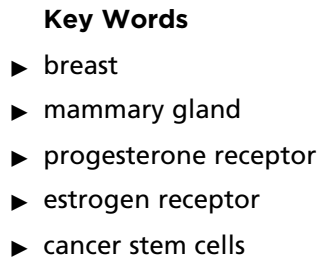

Endocrine-Related Cancer (2015) 22, T177-T186

\section{Breast cancer stem cells}

The cancer stem cell (CSC) theory proposes a hierarchical organization of the cells within a tumor, where only a small subset of cells, the CSCs, is believed to drive and sustain tumor growth. CSCs are defined as self-renewing tumor-initiating cells (TICs), which would implicate them in tumor relapse and resistance to therapy, making them an important therapeutic target (Reya et al. 2001).

The first report establishing the presence of breast CSCs (BCSCs) discovered that $\mathrm{CD} 44^{+} \mathrm{CD} 24^{-/{ }^{-10 w}} \mathrm{ESA}^{+}$lineage $^{-}$(named CD $44^{+} \mathrm{CD} 24^{-}$henceforth) cells, isolated from human breast tumors by FACS, were enriched for tumor-initiating capacity in immuno-compromised mice (Al-Hajj et al. 2003). CD $44^{+} \mathrm{CD} 24^{-}$cells can be serially passaged and form tumors containing both tumorigenic cells $\left(\mathrm{CD} 44^{+} \mathrm{CD} 24^{-}\right)$and non-tumorigenic cells. Breast cancers with high levels of CD44 and low levels of CD24 have been associated with the triple negative phenotype (i.e. lacking estrogen receptor (ER), progesterone receptor
(PR), and HER2 expression) and inferior overall survival (Liu et al. 2007, Honeth et al. 2008).

Besides isolation of $\mathrm{CD} 44^{+} \mathrm{CD} 24^{-}$cells, other strategies have been used to identify populations enriched for BCSC activity. Mammosphere formation, high aldehyde dehydrogenase (ALDH) activity, capacity to retain PKH26 dye or ability to efflux lipophilic dyes (side population (SP)), are all examples of properties that have been used to isolate these TICs. The mammosphere colony assay relies on the ability of BCSCs to survive in nonadherent serum-free culture conditions and form individual spherical colonies, called mammospheres (Dontu et al. 2003, Ponti et al. 2005, Farnie et al. 2007). On the other hand, the activity of ALDH1, which oxidizes intracellular aldehydes, is detected by an enzymatic assay (ALDEFLUOR) and flow cytometric analysis (Ginestier et al. 2007). The proportion of cells expressing ALDH1 in breast tumors has been shown to correlate with poor clinical outcome (Ginestier et al. 2007, Charafe-Jauffret et al. 2010).

This paper forms part of a thematic review section on Stem Cells and Cancer. The guest editor for this section was Dean Tang, The University of Texas MD Anderson Cancer Center, Smithville, TX USA Gaded from Bioscientifica.com at 04/26/2023 12:41:27PM 
The PKH26 dye, which labels quiescent cells, has also been used to identify BCSCs in primary breast tumors by FACS sorting cells expressing CD49f, DLL1, and DNER (Pece et al. 2010). Hoechst dye exclusion activity has also been described as a method to identify a cellular fraction termed the SP that contains tumorigenic stem/progenitor cells (Patrawala et al. 2005). Finally, an autofluorescent epithelial CSC phenotype has recently been reported, however it still remains to be proven whether it can be used to identify BCSCs (Miranda-Lorenzo et al. 2014).

There remains a lack of consensus as to the most robust method for the purification of BCSCs. The establishment of bona fide BCSC markers is hindered by breast cancer intra-tumor and inter-tumor heterogeneity of its cell populations. Nevertheless, the two most widely used cell populations to enrich for BCSCs are $\mathrm{CD}_{4}{ }^{+} \mathrm{CD} 24^{-}$and $\mathrm{ALDH}^{+}$.

A recent study reported that these two cell populations identify BCSCs in different states with gene expression profiles resembling cells with either mesenchymal $\left(\mathrm{CD} 44^{+} \mathrm{CD} 24^{-}\right.$cells) or epithelial characteristics $\left(\mathrm{ALDH}^{+}\right.$cells) (Liu et al. 2014). Moreover, this study identified a small overlapping population of cells that is both $\mathrm{CD} 44^{+} \mathrm{CD} 24^{-}$and $\mathrm{ALDH}^{+}$, and suggested that BCSCs display cellular plasticity by dynamically switching between the mesenchymal and epithelial states. This epithelial-mesenchymal transition or vice-versa (mesenchymal-epithelial transition) is believed to be determined by the tumor microenvironment, with factors like hypoxia or transforming growth factor beta playing a key role in this process (Thiery 2002, Yang et al. 2008). It is feasible that other signaling factors that have been reported to modulate BCSC activity, such as hormones, may also influence this dynamic state.

In this review, we will discuss what is known about the regulation of BCSC function by the steroid hormones estrogen and progesterone and their antagonists.

\section{Estrogen and BCSCs}

Estrogen is essential for the development of normal breast epithelium by promoting epithelial cell proliferation and ductal morphogenesis but also plays an important role in the growth of most breast cancers through their expression of ER (Bocchinfuso \& Korach 1997, Colditz 1998). Epidemiological evidence suggests that breast cancer risk is positively associated with post-menopausal levels of estrogen (Clemons \& Goss 2001). Estrogen effects are mainly mediated through binding to two nuclear ligand-activated transcription factors, the ERs ER $\alpha$ and
ER $\beta$, which then bind estrogen-responsive elements in the DNA to regulate the transcription of target genes (Yager \& Davidson 2006). In the normal breast, ER $\alpha$ is found in luminal epithelial cells, but not in the stroma, whereas ER $\beta$ has been shown to be expressed in both luminal and myoepithelial cells, as well as stromal cells, such as fibroblasts and endothelial cells (Petersen et al. 1987, Speirs et al. 2002). ER $\alpha$, which has a higher affinity to the physiological form of estrogen, $17 \beta$-estradiol, than ER $\beta$, has been shown to be the major mediator of estrogen action (Bocchinfuso \& Korach 1997, Kuiper et al. 1998). $\mathrm{ER} \alpha$ (named ER henceforth) is a key regulator of breast cancer and its expression status is currently used together with other receptors in the classification of breast cancer subtypes. $\mathrm{ER}^{+}$tumors are strongly associated with the luminal subtype and are generally characterized by expression of luminal differentiation markers (Perou et al. 2000).

Although the importance of estrogen in breast cancer is well established, the effects of estrogen on BCSCs are not fully understood and are still a matter of debate (Simões \& Vivanco 2011). Estrogen may exert influence on stem cells via paracrine mechanisms because $\mathrm{CD} 44^{+} \mathrm{CD} 24^{-}$and $\mathrm{ALDH}^{+} \mathrm{CSC}$ have been shown to lack expression of ER or express it at very low levels (Morimoto et al. 2009, Harrison et al. 2013, Simões et al. 2015). Similar to what happens in the normal mammary gland, it has been suggested that estrogen can promote CSC activity of $\mathrm{ER}^{-}$BCSCs by inducing the secretion of paracrine growth factors from $\mathrm{ER}^{+}$cells. Fibroblast growth factor (FGF)/Tbx3 signalling, as well as epidermal growth factor (EGF) and Notch receptor signalling pathways, have been reported to control this paracrine mechanism and induce the expansion of CD $44^{+} \mathrm{CD} 24^{-}$CSCs (Fillmore et al. 2010, Harrison et al. 2013). In contrast to these findings, estrogen was shown to reduce the self-renewal capacity of MCF7 BCSCs by promoting differentiation through down-regulation of embryonic stem cell genes NANOG, OCT4, and SOX2 (Simões et al. 2011). These contradictory results may be due to differences in the methods used in these studies. Fillmore et al. and Harrison et al. exposed breast cancer cells grown in monolayer adherent culture (not enriched for CSCs) to estrogen whereas Simões et al. challenged BCSCs with estrogen by growing cells in non-adherent mammosphere culture conditions. Therefore, opposing effects of estrogen on CSC activity seem to be determined by the context in which the cells are cultured and by the analysis of different breast cancer cell populations.

The role of estrogen in clinical breast carcinogenesis is also contradictory. Whereas high levels of endogenous

Published by Bioscientifica Ltd. 
estrogens increase the risk of postmenopausal breast cancer, randomised trials of exogenous estrogen alone (hormone replacement therapy) show it to reduce the incidence and mortality of breast cancer (Women's Health Initiative) (LaCroix et al. 2011). This finding is similar to animal models where short-term treatment with pregnancy levels of estrogen can prevent the formation of mammary tumors (Rajkumar et al. 2001). This anti-cancer effect of estrogen has been suggested to explain the breast cancer preventative potential of early full-term pregnancy to lifetime breast cancer risk, although this cannot be attributed solely to estrogen levels given the complexity of pregnancy associated endocrine perturbation (Medina 2004). Hypothetically, the protective effect of estrogen may be due to breast stem cell differentiation during pregnancy and lactation, which would reduce the number of stem cells that could be precursors of cancer (Russo et al. 2005, Simões \& Vivanco 2011). To add further complexity to the role of estrogen in breast cancer, higher doses have been used for many years to treat advanced disease, with response rates similar to those seen with the anti-estrogens (Ellis et al. 2009, Lewis-Wambi \& Jordan 2009). Without doubt, more studies are needed to explore the complexities of estrogen signalling, stem cells and breast cancer risk and progression.

\section{Endocrine resistance: biomarkers, up-regulated pathways, and BCSCs}

Around $75 \%$ of breast cancers express ER and are treated with anti-estrogen adjuvant therapies to suppress ER mediated estrogen signaling and, therefore, inhibit proliferation of $\mathrm{ER}^{+}$breast cancer cells (Ali \& Coombes 2002). There are three main classes of anti-estrogen drugs that target and modulate ER activity: selective ER modulators (SERMs), aromatase inhibitors (AIs), and selective ER down-regulators (SERDs). The most common and successful SERM is tamoxifen, which prevents the effects of estrogen by competing for the ER ligand-binding site (Shiau et al. 1998). AIs block the function of aromatase, the enzyme that catalyses the last step of estrogen biosynthesis (Mokbel 2002). Tamoxifen and AIs are the endocrine therapies of choice in the adjuvant treatment of premenopausal and postmenopausal women respectively (Beelen et al. 2012). These and other antiestrogens, such as the SERD fulvestrant, which binds ER and targets it for degradation through ubiquitination, are used sequentially in advanced breast cancer (Howell et al. 2004). Endocrine sensitivity can partly be predicted by serial analysis of the proliferation marker Ki67 expression in pre-surgical 'window' studies or longer term neoadjuvant studies of several months of treatment (Dowsett et al. 2011). More recently, a four-gene signature including genes related to immune signalling (IL6ST), apoptosis (NGFRAP1), and proliferation (ASPM and MCM4) was reported to predict the clinical response of patients treated with AIs (Turnbull et al. 2015). However, despite the undoubted success of tamoxifen (or similar endocrine) treatment, at least half of patients with micrometastatic disease will relapse despite therapy, often many years after initial surgery and endocrine therapy is completed (Early Breast Cancer Trialists' Collaborative Group et al. 2011).

Such endocrine resistance compromises this otherwise effective treatment and thus the potential cure of $\mathrm{ER}^{+}$ breast cancers. Therefore, defining the mechanisms of endocrine resistance is a major research focus. Activation of classical signalling pathways, including the ones induced by HER2 and EGF receptor (EGFR), MAPK, and PI3K/AKT have been implicated in hormone resistance (Musgrove \& Sutherland 2009). However, the only approved targeted therapies to improve outcomes of endocrine-resistant $\mathrm{ER}^{+}$ HER $2^{-}$breast cancers are the MTOR inhibitor everolimus and the CDK4/6 inhibitor palbociclib combined with an AI or fulvestrant (Baselga et al. 2012, Finn et al. 2015, Turner et al. 2015). Therefore, a better understanding of the molecular changes associated with endocrine resistant growth is urgently needed to find treatments that can inhibit or delay the emergence of resistance.

BCSCs, which can survive for long periods in a dormant state, may be associated with tumor recurrence and metastases. These cells have been shown to be more resistant to chemo- and radio-therapies than non-CSCs (Phillips et al. 2006, Li et al. 2008). In endocrine therapy, accumulating evidence suggests that there is an increase in BCSCs in $\mathrm{ER}^{+}$breast cancer following anti-estrogen treatment. Two studies have reported enrichment for cells with both BCSC gene and marker expression in breast tumor tissue following short term AI (letrozole) or tamoxifen treatment (Creighton et al. 2010, Kabos et al. 2011). Additionally, other studies demonstrated similar effects in $\mathrm{ER}^{+}$breast cancer cell lines. For example, tamoxifen treatment increased both the number of mammospheres and the expression of NANOG, OCT4, and SOX2 in MCF7 breast cancer cells (Simões et al. 2011, Piva et al. 2014). MCF7 mammospheres were also shown to be resistant to high doses of tamoxifen (Cariati et al. 2008). Moreover, tamoxifen, fulvestrant, or estrogen deprivation increased the percentage of cells expressing cytokeratin 5 (CK5), a marker of human breast stem/progenitor cells also found in BCSCs, in T47D breast cancer cells (Creighton

Published by Bioscientifica Ltd. 
et al. 2010, Kabos et al. 2011). These data confirm that, while endocrine therapies target the differentiated proliferative breast cancer cells, they cannot effectively target the BCSCs.

Stem cell activity in $\mathrm{ER}^{+}$tumors is mainly due to a minority population of $\mathrm{ER}^{-}$cells, which cannot be directly targeted by anti-estrogens and therefore might be responsible for resistance and recurrence (Harrison et al. 2013, Simões et al. 2015). Indeed, circulating tumor cells of $\mathrm{ER}^{+}$primary tumors are in general found to be $\mathrm{ER}^{-}$(Fehm et al. 2009). In the clinic, ER negativity is associated with poor prognosis, precluding a response to all categories of anti-estrogen treatment and associating with a more aggressive and proliferative phenotype. Interestingly, expression of putative regulators of $\mathrm{ER}^{-}$BCSC activity like EGFR (Harrison et al. 2013), HER2 (Ithimakin et al. 2013), and FGF receptor (Fillmore et al. 2010), potentially resulting from selection of cells with a more stem-like phenotype have been associated with acquisition of endocrine resistance (McClelland et al. 2001, Hutcheson et al. 2003, Knowlden et al. 2003). Recently, the ER splice variant ER $\alpha 36$, which lacks both transactivation domains AF1 and AF2, was associated with BCSC regulation and endocrine resistance (Wang et al. 2005, Deng et al. 2014). Specifically, Deng et al. showed ER $\alpha 36$ to be essential for CD $44^{+} \mathrm{CD} 24^{-}$BCSC enrichment induced by tamoxifen or fulvestrant. ER $\alpha 36$ is reported to be located in the cellular membrane and cytoplasm, and to rapidly activate MAPK/ERK signalling in the presence of estrogen. However, future studies are needed to better understand the importance of ER $\alpha 36$ isoform in BCSCs maintenance (Wang et al. 2006).

The potential involvement of BCSCs in endocrine resistance makes it imperative to understand the cellular signalling pathways that could be targeted to eradicate BCSCs and provide long-term disease-free survival. It has been established that these cells are dependent upon developmental signalling pathways, which may provide suitable targets for therapeutic intervention (reviewed in Visvader \& Lindeman (2012)). For example, activation of Wnt signalling due to high expression levels of stem cell marker SOX2 has been reported as an important tamoxifen-resistance mechanism (Piva et al. 2014). Another strong candidate for endocrine-resistant CSC regulation is the Notch pathway, which comprises four different transmembrane receptors (Notch1-4), five known surfacebound ligands (Delta-like 1, Delta-like 3, Delta-like 4, Jagged 1, and Jagged 2) and multiple transcriptional targets, including the Hes and Hey family of genes (Brennan \& Brown 2003). It was previously shown that aberrant Notch activation is found in human breast cancers and correlates with recurrence within 5 years in ductal carcinoma in situ (DCIS) lesions (Stylianou et al. 2006, Farnie et al. 2007). Moreover, it was established that inhibition of the Notch signalling pathway reduces BCSC activity, and that the Notch4 receptor has a key role in controlling BCSCs (Harrison et al. 2010). Recently, our group demonstrated that treating $\mathrm{ER}^{+}$breast cancer cells with endocrine therapies leads to increased Jag1-Notch4 signalling and that combining endocrine therapies with a Notch pathway inhibitor can prevent BCSC enrichment induced by endocrine therapies (Simões et al. 2015). Our results suggest that inhibition of Notch signalling can help overcoming endocrine therapy resistance and might prevent recurrence in $\mathrm{ER}^{+}$breast cancer. Importantly, we also showed that both Notch4 activation and high expression of BCSC marker ALDH1 in patient primary tumors are predictors of resistance to endocrine treatments (Simões et al. 2015).

In summary, we speculate that BCSCs evade endocrine therapies, lie dormant and eventually re-initiate tumors in metastatic sites after treatment. Thus, BCSC-targeted therapies in combination with established anti-estrogens are likely to improve outcomes for breast cancer patients.

\section{Progesterone and BCSCs}

Progesterone has been shown to be vital for both pubertal side branching and lobular alveolar development of the mammary gland during pregnancy (Lydon et al. 1995, Brisken 2013). Importantly, in premenopausal women breast epithelial cell proliferation is highest in the progesterone dominant luteal phase of the menstrual cycle (Potten et al. 1988, Navarrete et al. 2005). Studies in mice have shown that mammary gland development results from progesterone-induced expansion of the mammary stem cell pool and have also shown that PR is important for carcinogen-induced mammary tumor formation (Lydon et al. 1999, Asselin-Labat et al. 2010, Joshi et al. 2010). In normal human breast cells, progesterone stimulation in matrix-embedded culture increased bipotent progenitor cell numbers (Graham et al. 2009).

The progesterone signal is mediated by the $\mathrm{PR}$, which comprises two isoforms (PRA and PRB) that are only differentiated by a third activation function domain on the $5^{\prime}$ end of PRB (Kastner et al. 1990). The two isoforms are generally co-expressed at similar levels in the normal breast but the ratio can be altered in human breast tumors, resulting in a predominance of one particular isoform, usually PRA, over its counterpart (Graham et al. 2005, 2009).

Published by Bioscientifica Ltd. 
Isoform-specific mouse mutants reveal that PRB is the functionally important form in mammary gland morphogenesis, whereas PRA is important for ovarian function (Mulac-Jericevic et al. 2000, 2003). These isoforms display only partially overlapping transcriptional signatures with PRB modulating expression of significantly more genes than PRA (Richer et al. 2002). Relative loss of PRB is seen with the development of atypia or malignancy and in women with germline mutations in BRCA1 or BRCA2 (Mote et al. 2002). Interestingly, women with such mutations have double the serum progesterone levels compared to age matched WT controls although the significance of this finding is not known (Widschwendter et al. 2013).

In the normal mammary tissue, progesterone-induced gland expansion is mediated through paracrine proliferative signals, including receptor activator of nuclear factor-kappa B ligand (RANKL) and WNT4, secreted from $\mathrm{PR}^{+}$sensor cells and acting on $\mathrm{PR}^{-}$stem cells, expressing the RANK receptor and Wnt receptors, such as Frizzled (FZD) and LRP5/6 (Graham et al. 2009, Gonzalez-Suarez et al. 2010, Joshi et al. 2010). In multiple rodent models, deletion or inhibition of PR or the RANK/RANKL pathway results in significant reduction in mammary carcinogenesis (Lydon et al. 1999, Poole et al. 2006, Gonzalez-Suarez et al . 2010, Schramek et al. 2010). Recent evidence has established CXCR4 receptor and its ligand CXCL12 as potential key mediators of progesterone-induced stem/progenitor cell functions in normal mammary gland (Shiah et al. 2015). CXCL12 is localized on $\mathrm{PR}^{+}$luminal cells whereas CXCR4 is induced by progesterone in both basal and luminal $\mathrm{PR}^{-}$cells. Significantly, Shiah et al. showed that inhibition of CXCR4-CXCL12 signalling is able to arrest the progesterone-induced expansion of mammary stem/progenitor cells. Finally, it has been demonstrated recently that progesterone induces growth hormone (GH) secretion in human breast epithelial cells, which increases proliferation of GH receptor (GHR) positive stem/ progenitor breast cells (Lombardi et al. 2014).

In an analogous manner progesterone has been shown to expand the population of BCSCs in breast cancer cell lines. In particular, progesterone was shown to increase the population of $\mathrm{CK}^{+}$and $\mathrm{CD} 44^{\mathrm{hi}}$ or $\mathrm{CD} 44^{+} \mathrm{CD} 24^{-}$ BCSCs in several $\mathrm{ER}^{+} \mathrm{PR}^{+}$cell lines but particularly in T47D cells, which express high levels of PR even in the absence of estrogen (Axlund et al. 2013, Finlay-Schultz et al. 2014, Hilton et al. 2014). Importantly, in cell lines where PR expression is dependent on estrogen, cells need to be treated with estrogen and progesterone, while estrogen alone was not able to induce BCSCs.
The mechanisms behind the progesterone-induced expansion of BCSCs have not been fully elucidated. However, progesterone treatment of cell lines has been shown to repress miR-29 and miR-141, de-repressing KLF4 and STAT5A respectively (Cittelly et al. 2013, FinlaySchultz et al. 2014). In both studies, this resulted in expansion of the $\mathrm{CK} 5^{+} / \mathrm{CD} 44^{+} \mathrm{CSC}$ population and enhancement of colony formation and tumor initiating capacity. KLF4 is a transcription factor required for maintenance of both BCSCs (Yu et al. 2011) and pluripotency in embryonic stem cells (Zhang et al. 2010) whereas STAT5A is a transcription factor that regulates the mammary luminal progenitor population (Yamaji et al. 2009). BCL6, which appears to be critical in the maintenance of some leukaemic stem cells, was also reported to be essential for progesterone-induction of $\mathrm{CK}^{+}$cells (Hurtz et al. 2011, Sato et al. 2014). Interestingly, the progesteroneinduced expression of BCL6 was inhibited by prolactin, further demonstrating the complex interplay between hormonal signalling axes in the regulation of BCSCs (Sato et al. 2014). It is also possible that $\mathrm{PR}^{+}$cells communicate with $\mathrm{PR}^{-}$BCSCs through similar paracrine pathways as in the normal mammary gland. Indeed, non-endogenous overexpression of RANK in human breast cell lines induces stemness by increasing the $\mathrm{CD} 44^{+} \mathrm{CD} 24^{-}$BCSC population, promoting tumour initiation and metastasis (Palafox et al. 2012). However, clinical trials of the RANKL inhibitor denosumab do not show any improvement in cancer control or survival despite their valuable role in reducing skeletal complications from bone metastases. In summary, this evidence suggests that progesterone is responsible for the expansion of both normal and breast cancer stem cells but that the precise mechanisms may be divergent. However, both the PR itself and some of the paracrine/downstream signals described are targetable and may hold promise as breast cancer therapies.

\section{Anti-progesterone drugs and BCSCs}

Women's Health Initiative study reports that combination of estrogen with progestin (synthetic progesterone derivative), but not estrogen alone was associated with greater breast cancer incidence and mortality (Chlebowski et al. 2010). The progesterone role in mammary tumorigenesis may be explained by the expansion of stem cell populations, which are likely to originate $\mathrm{BCSCs}$ and lead to the formation of $\mathrm{ER}^{+} \mathrm{PR}^{+}$ tumors (Narod 2011).

Despite much promise in the early 1990s, no anti-progestin is a recommended standard of care in

Published by Bioscientifica Ltd 


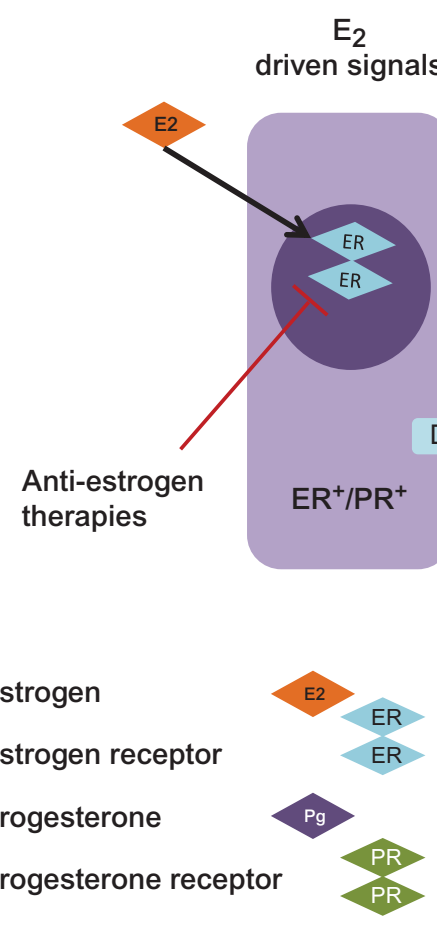

Figure 1

Schematic representation of paracrine and juxtacrine signals involved in estrogen and progesterone regulation of BCSCs. Estrogen and progesterone bind estrogen receptor (ER) and progesterone receptor (PR) nuclear transcription factors, respectively, regulating expression of target genes. Estrogen sensor cells (non-BCSCs) increase transcription of epidermal growth factor (EGF), amphiregulin (AREG), transforming growth factor alpha (TGF $\alpha$ ), and fibroblast growth factor (FGF), which will signal to the BCSCs through the EGFRs and FGFRs. Non-BCSCs can also signal to the

anti-cancer treatment. However, there is a renewed interest in anti-progestin drugs indicated by several current clinical trials using mifepristone and onapristone in breast cancer and other solid tumors (see NCT01493310, NCT02014337, NCT02046421, NCT02049190, and NCT02052128 on US clinical trials database, https:// clinicaltrials.gov/). Based on recent research, it is possible that these drugs target $\mathrm{BCSC}$ in $\mathrm{ER}^{+} \mathrm{PR}^{+}$tumors, although this remains hypothetical and merits further investigation.

\section{Conclusions}

The published data suggests that in breast cancer both estrogen and progesterone signalling have multifarious effects on CSC activity. Since BCSCs are reported to be low or negative for steroid hormone receptors, the effects are likely to be mainly indirect, transmitted through
$\mathrm{Pg}$

driven signals

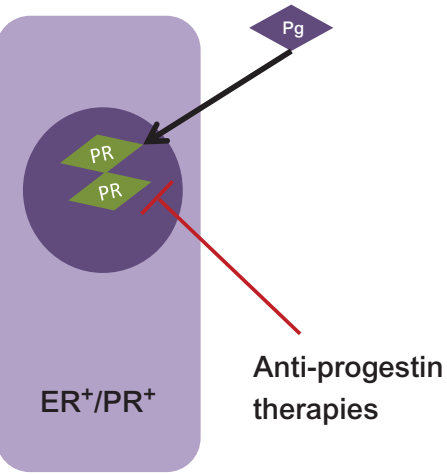

BCSCs via Notch signalling. Progesterone sensor cells (non-BCSCs) also increase transcription of several important signalling factors. Progesterone regulation of BCSCS may occur via activation of RANK/RANKL, Wnt receptors/Wnt4, CXCR4/CXCL12, and GHR/GH paracrine signalling (dashed lines). Estrogen and progesterone-induced signals can be blocked by anti-estrogens (e.g. tamoxifen and fulvestrant) and anti-progesterone drugs (e.g. mifepristone and onapristone).

paracrine or juxtacrine cell-cell signalling pathways (Fig. 1). We do not exclude the possibility that there is some autocrine signalling downstream of hormones that may contribute to regulation of BCSCs. The effects of estrogen and progesterone have only been partially described in cancer tissues. For progesterone in particular there is more data from normal mammary epithelium than from cancer tissues.

For estrogen, there are reports that following in vitro treatment of serum-starved breast cancer cells, CSC activity is stimulated and that this requires regulation by EGF, FGF, or Notch1 receptors, suggesting indirect, paracrine or juxtacrine signalling between cells (Fig. 1). On the other hand, anti-estrogens, such as tamoxifen or fulvestrant, block direct effects of estrogens on cell growth, and the indirect signals to the $\mathrm{ER}^{-}$BCSCs. Paradoxically however, tamoxifen has been demonstrated to increase 
BCSC activity in mammosphere colony culture (Simões et al. 2011, Piva et al. 2014), and more recently, the same has been confirmed for both tamoxifen and fulvestrant in vivo (Simões et al. 2015). The data suggest that while anti-estrogens are cytostatic for the $\mathrm{ER}^{+}$cells, there is an increase in the proportion of $\mathrm{ER}^{-}$BCSCs and their activity. This increase could be due to selective enrichment by treatment, by induction of a change in cellular phenotype from $\mathrm{ER}^{+}$non-BCSC to $\mathrm{ER}^{-} \mathrm{BCSC}$, or possibly a combination of both of these effects. Whatever the reason, the mechanism for the increase induced by anti-estrogens is reported to be Jag1-Notch4 signalling between $\mathrm{ER}^{-}$ BCSCs (Simões et al. 2015), rather than the signals from the $\mathrm{ER}^{+}$cell shown here (Fig. 1).

For progesterone, the data are clear it has a role in regulating the expansion of normal mammary stem and progenitor cells through several signalling pathways including CXCL12/CXCR4, GH/GHR, WNT4/FZD, and RANKL/RANK. In breast cancer, there are cell line data suggesting that progesterone may regulate BCSCs but the importance of the previous signalling networks is not established (Fig. 1). Since progesterone does not directly stimulate proliferation in most breast cancers, the role for anti-progesterone drugs in breast cancer may be to abrogate progesterone effects on BCSC activities, although this is yet to be proven.

In summary, the data accumulated thus far indicate that estrogen and progesterone have mostly indirect effects on BCSCs since they are mainly $\mathrm{ER}^{-}$and $\mathrm{PR}^{-}$ cells. Results from both normal and malignant epithelial cell-cell interactions suggest that estrogen and progesterone elicit these effects through different paracrine/ juxtacrine regulatory pathways. Finally, since there are several putative pathways downstream of each estrogen and progesterone, there will be interactions and redundancy between these, yielding a subtle complexity in the consequences for the BCSC.

\section{Declaration of interest}

The authors declare that there is no conflict of interest that could be perceived as prejudicing the impartiality of the review.

\section{Funding}

The authors' work is supported by funding from Breast Cancer Now.

\section{Acknowledgements}

The authors would like to apologize to those authors whose work was not cited due to space limitations.

\section{References}

Al-Hajj M, Wicha MS, Benito-Hernandez A, Morrison SJ \& Clarke MF 2003 Prospective identification of tumorigenic breast cancer cells. PNAS 100 3983-3988. (doi:10.1073/pnas.0530291100)

Ali S \& Coombes RC 2002 Endocrine-responsive breast cancer and strategies for combating resistance. Nature Reviews. Cancer 2 101-112. (doi:10.1038/nrc721)

Asselin-Labat ML, Vaillant F, Sheridan JM, Pal B, Wu D, Simpson ER, Yasuda H, Smyth GK, Martin TJ, Lindeman GJ et al. 2010 Control of mammary stem cell function by steroid hormone signalling. Nature 465 798-802. (doi:10.1038/nature09027)

Axlund SD, Yoo BH, Rosen RB, Schaack J, Kabos P, Labarbera DV \& Sartorius CA 2013 Progesterone-inducible cytokeratin 5-positive cells in luminal breast cancer exhibit progenitor properties. Hormones \& Cancer 4 36-49. (doi:10.1007/s12672-012-0127-5)

Baselga J, Campone M, Piccart M, Burris HA III, Rugo HS, Sahmoud T, Noguchi S, Gnant M, Pritchard KI, Lebrun F et al. 2012 Everolimus in postmenopausal hormone-receptor-positive advanced breast cancer. New England Journal of Medicine 366 520-529. (doi:10.1056/ NEJMoa1109653)

Beelen K, Zwart W \& Linn SC 2012 Can predictive biomarkers in breast cancer guide adjuvant endocrine therapy? Nature Reviews. Clinical Oncology 9 529-541. (doi:10.1038/nrclinonc.2012.121)

Bocchinfuso WP \& Korach KS 1997 Mammary gland development and tumorigenesis in estrogen receptor knockout mice. Journal of Mammary Gland Biology and Neoplasia 2 323-334. (doi:10.1023/ A:1026339111278)

Brennan K \& Brown AM 2003 Is there a role for Notch signalling in human breast cancer? Breast Cancer Research 5 69-75. (doi:10.1186/bcr559)

Brisken C 2013 Progesterone signalling in breast cancer: a neglected hormone coming into the limelight. Nature Reviews. Cancer 13 385-396. (doi:10.1038/nrc3518)

Cariati M, Naderi A, Brown JP, Smalley MJ, Pinder SE, Caldas C \& Purushotham AD 2008 Alpha-6 integrin is necessary for the tumourigenicity of a stem cell-like subpopulation within the MCF7 breast cancer cell line. International Journal of Cancer 122 298-304. (doi:10.1002/ijc.23103)

Charafe-Jauffret E, Ginestier C, Iovino F, Tarpin C, Diebel M, Esterni B, Houvenaeghel G, Extra JM, Bertucci F, Jacquemier J et al. 2010 Aldehyde dehydrogenase 1-positive cancer stem cells mediate metastasis and poor clinical outcome in inflammatory breast cancer. Clinical Cancer Research 16 45-55. (doi:10.1158/1078-0432. CCR-09-1630)

Chlebowski RT, Anderson GL, Gass M, Lane DS, Aragaki AK, Kuller LH, Manson JE, Stefanick ML, Ockene J, Sarto GE et al. 2010 Estrogen plus progestin and breast cancer incidence and mortality in postmenopausal women. Journal of the American Medical Association 304 1684-1692. (doi:10.1001/jama.2010.1500)

Cittelly DM, Finlay-Schultz J, Howe EN, Spoelstra NS, Axlund SD, Hendricks P, Jacobsen BM, Sartorius CA \& Richer JK 2013 Progestin suppression of miR-29 potentiates dedifferentiation of breast cancer cells via KLF4. Oncogene 32 2555-2564. (doi:10.1038/onc.2012.275)

Clemons M \& Goss P 2001 Estrogen and the risk of breast cancer. New England Journal of Medicine 344 276-285. (doi:10.1056/ NEJM200101253440407)

Colditz GA 1998 Relationship between estrogen levels, use of hormone replacement therapy, and breast cancer. Journal of the National Cancer Institute 90 814-823. (doi:10.1093/jnci/90.11.814)

Creighton CJ, Chang JC \& Rosen JM 2010 Epithelial-mesenchymal transition (EMT) in tumor-initiating cells and its clinical implications in breast cancer. Journal of Mammary Gland Biology and Neoplasia 15 253-260. (doi:10.1007/s10911-010-9173-1)

Deng H, Zhang X-T, Wang M-L, Zheng H-Y, Liu L-J \& Wang Z-Y 2014 ER- $\alpha 36-$ mediated rapid estrogen signaling positively regulates 
ER-positive breast cancer stem/progenitor cells. PLoS ONE 9 e88034. (doi:10.1371/journal.pone.0088034)

Dontu G, Abdallah WM, Foley JM, Jackson KW, Clarke MF, Kawamura MJ \& Wicha MS 2003 In vitro propagation and transcriptional profiling of human mammary stem/progenitor cells. Genes and Development 17 1253-1270. (doi:10.1101/gad.1061803)

Dowsett M, Nielsen TO, A'Hern R, Bartlett J, Coombes RC, Cuzick J, Ellis M, Henry NL, Hugh JC, Lively T et al. 2011 Assessment of Ki67 in breast cancer: recommendations from the International Ki67 in Breast Cancer working group. Journal of the National Cancer Institute 103 1656-1664. (doi:10.1093/jnci/djr393)

Early Breast Cancer Trialists' Collaborative Group , Davies C, Godwin J, Gray R, Clarke M, Cutter D, Darby S, McGale P, Pan HC, Taylor C et al. 2011 Relevance of breast cancer hormone receptors and other factors to the efficacy of adjuvant tamoxifen: patient-level meta-analysis of randomised trials. Lancet 378 771-784. (doi:10.1016/S01406736(11)60993-8)

Ellis MJ, Gao F, Dehdashti F, Jeffe DB, Marcom PK, Carey LA, Dickler MN, Silverman P, Fleming GF, Kommareddy A et al. 2009 Lower-dose vs high-dose oral estradiol therapy of hormone receptor-positive, aromatase inhibitor-resistant advanced breast cancer: a phase 2 randomized study. Journal of the American Medical Association 302 774-780. (doi:10.1001/jama.2009.1204)

Farnie G, Clarke RB, Spence K, Pinnock N, Brennan K, Anderson NG \& Bundred NJ 2007 Novel cell culture technique for primary ductal carcinoma in situ: role of Notch and epidermal growth factor receptor signaling pathways. Journal of the National Cancer Institute 99 616-627. (doi:10.1093/jnci/djk133)

Fehm T, Hoffmann O, Aktas B, Becker S, Solomayer EF, Wallwiener D, Kimmig R \& Kasimir-Bauer S 2009 Detection and characterization of circulating tumor cells in blood of primary breast cancer patients by RT-PCR and comparison to status of bone marrow disseminated cells. Breast Cancer Research 11 R59. (doi:10.1186/bcr2349)

Fillmore CM, Gupta PB, Rudnick JA, Caballero S, Keller PJ, Lander ES \& Kuperwasser C 2010 Estrogen expands breast cancer stem-like cells through paracrine FGF/Tbx3 signaling. PNAS 107 21737-21742. (doi:10.1073/pnas.1007863107)

Finlay-Schultz J, Cittelly DM, Hendricks P, Patel P, Kabos P, Jacobsen BM, Richer JK \& Sartorius CA 2014 Progesterone downregulation of miR-141 contributes to expansion of stem-like breast cancer cells through maintenance of progesterone receptor and Stat5a. Oncogene $\mathbf{3 4}$ 3676-3687. (doi:10.1038/onc.2014.298)

Finn RS, Crown JP, Lang I, Boer K, Bondarenko IM, Kulyk SO, Ettl J, Patel R, Pinter T, Schmidt M et al. 2015 The cyclin-dependent kinase 4/6 inhibitor palbociclib in combination with letrozole versus letrozole alone as first-line treatment of oestrogen receptor-positive, HER2negative, advanced breast cancer (PALOMA-1/TRIO-18): a randomised phase 2 study. Lancet. Oncology 16 25-35. (doi:10.1016/S14702045(14)71159-3)

Ginestier C, Hur MH, Charafe-Jauffret E, Monville F, Dutcher J, Brown M, Jacquemier J, Viens P, Kleer CG, Liu S et al. 2007 ALDH1 is a marker of normal and malignant human mammary stem cells and a predictor of poor clinical outcome. Cell Stem Cell 1 555-567. (doi:10.1016/j.stem. 2007.08.014)

Gonzalez-Suarez E, Jacob AP, Jones J, Miller R, Roudier-Meyer MP, Erwert R, Pinkas J, Branstetter D \& Dougall WC 2010 RANK ligand mediates progestin-induced mammary epithelial proliferation and carcinogenesis. Nature 468 103-107. (doi:10.1038/nature09495)

Graham JD, Yager ML, Hill HD, Byth K, O'Neill GM \& Clarke CL 2005 Altered progesterone receptor isoform expression remodels progestin responsiveness of breast cancer cells. Molecular Endocrinology 19 2713-2735. (doi:10.1210/me.2005-0126)

Graham JD, Mote PA, Salagame U, van Dijk JH, Balleine RL, Huschtscha LI, Reddel RR \& Clarke CL 2009 DNA replication licensing and progenitor numbers are increased by progesterone in normal human breast. Endocrinology 150 3318-3326. (doi:10.1210/en.2008-1630)
Harrison H, Farnie G, Howell SJ, Rock RE, Stylianou S, Brennan KR, Bundred NJ \& Clarke RB 2010 Regulation of breast cancer stem cell activity by signaling through the Notch4 receptor. Cancer Research 70 709-718. (doi:10.1158/0008-5472.CAN-09-1681)

Harrison H, Simões BM, Rogerson L, Howell SJ, Landberg G \& Clarke RB 2013 Oestrogen increases the activity of oestrogen receptor negative breast cancer stem cells through paracrine EGFR and Notch signalling. Breast Cancer Research 15 R21. (doi:10.1186/bcr3396)

Hilton HN, Santucci N, Silvestri A, Kantimm S, Huschtscha LI, Graham JD \& Clarke CL 2014 Progesterone stimulates progenitor cells in normal human breast and breast cancer cells. Breast Cancer Research and Treatment 143 423-433. (doi:10.1007/s10549-013-2817-2)

Honeth G, Bendahl PO, Ringner M, Saal LH, Gruvberger-Saal SK, Lovgren K, Grabau D, Ferno M, Borg A \& Hegardt C 2008 The CD44 ${ }^{+} / \mathrm{CD} 24^{-}$ phenotype is enriched in basal-like breast tumors. Breast Cancer Research 10 R53. (doi:10.1186/bcr2108)

Howell A, Robertson JF, Abram P, Lichinitser MR, Elledge R, Bajetta E, Watanabe T, Morris C, Webster A, Dimery I et al. 2004 Comparison of fulvestrant versus tamoxifen for the treatment of advanced breast cancer in postmenopausal women previously untreated with endocrine therapy: a multinational, double-blind, randomized trial. Journal of Clinical Oncology 22 1605-1613. (doi:10.1200/JCO.2004.02.112)

Hurtz C, Hatzi K, Cerchietti L, Braig M, Park E, Kim YM, Herzog S, Ramezani-Rad P, Jumaa H, Muller MC et al. 2011 BCL6-mediated repression of p53 is critical for leukemia stem cell survival in chronic myeloid leukemia. Journal of Experimental Medicine 208 2163-2174. (doi:10.1084/jem.20110304)

Hutcheson IR, Knowlden JM, Madden TA, Barrow D, Gee JM, Wakeling AE \& Nicholson RI 2003 Oestrogen receptor-mediated modulation of the EGFR/MAPK pathway in tamoxifen-resistant MCF-7 cells. Breast Cancer Research and Treatment 81 81-93. (doi:10.1023/ A:1025484908380)

Ithimakin S, Day KC, Malik F, Zen Q, Dawsey SJ, Bersano-Begey TF, Quraishi AA, Ignatoski KW, Daignault S, Davis A et al. 2013 HER2 drives luminal breast cancer stem cells in the absence of HER2 amplification: implications for efficacy of adjuvant trastuzumab. Cancer Research $\mathbf{7 3}$ 1635-1646. (doi:10.1158/0008-5472.CAN-12-3349)

Joshi PA, Jackson HW, Beristain AG, Di Grappa MA, Mote PA, Clarke CL, Stingl J, Waterhouse PD \& Khokha R 2010 Progesterone induces adult mammary stem cell expansion. Nature 465 803-807. (doi:10.1038/ nature09091)

Kabos P, Haughian JM, Wang X, Dye WW, Finlayson C, Elias A, Horwitz KB \& Sartorius CA 2011 Cytokeratin 5 positive cells represent a steroid receptor negative and therapy resistant subpopulation in luminal breast cancers. Breast Cancer Research and Treatment 128 45-55. (doi:10.1007/s10549-010-1078-6)

Kastner P, Krust A, Turcotte B, Stropp U, Tora L, Gronemeyer H \& Chambon P 1990 Two distinct estrogen-regulated promoters generate transcripts encoding the two functionally different human progesterone receptor forms A and B. EMBO Journal 9 1603-1614.

Knowlden JM, Hutcheson IR, Jones HE, Madden T, Gee JM, Harper ME, Barrow D, Wakeling AE \& Nicholson RI 2003 Elevated levels of epidermal growth factor receptor/c-erbB2 heterodimers mediate an autocrine growth regulatory pathway in tamoxifen-resistant MCF-7 cells. Endocrinology 144 1032-1044. (doi:10.1210/en.2002-220620)

Kuiper GG, Lemmen JG, Carlsson B, Corton JC, Safe SH, van der Saag PT, van der Burg B \& Gustafsson JA 1998 Interaction of estrogenic chemicals and phytoestrogens with estrogen receptor $\beta$. Endocrinology $1394252-4263$.

LaCroix AZ, Chlebowski RT, Manson JE, Aragaki AK, Johnson KC, Martin L, Margolis KL, Stefanick ML, Brzyski R, Curb JD et al. 2011 Health outcomes after stopping conjugated equine estrogens among postmenopausal women with prior hysterectomy: a randomized controlled trial. Journal of the American Medical Association 305 1305-1314 (doi:10.1001/jama.2011.382) 
Lewis-Wambi JS \& Jordan VC 2009 Estrogen regulation of apoptosis: how can one hormone stimulate and inhibit? Breast Cancer Research 11206. (doi:10.1186/bcr2255)

Li X, Lewis MT, Huang J, Gutierrez C, Osborne CK, Wu MF, Hilsenbeck SG, Pavlick A, Zhang X, Chamness GC et al. 2008 Intrinsic resistance of tumorigenic breast cancer cells to chemotherapy. Journal of the National Cancer Institute 100 672-679. (doi:10.1093/jnci/djn123)

Liu R, Wang X, Chen GY, Dalerba P, Gurney A, Hoey T, Sherlock G, Lewicki J, Shedden K \& Clarke MF 2007 The prognostic role of a gene signature from tumorigenic breast-cancer cells. New England Journal of Medicine 356 217-226. (doi:10.1056/NEJMoa063994)

Liu S, Cong Y, Wang D, Sun Y, Deng L, Liu Y, Martin-Trevino R, Shang L, McDermott SP, Landis MD et al. 2014 Breast cancer stem cells transition between epithelial and mesenchymal states reflective of their normal counterparts. Stem Cell Reports 2 78-91. (doi:10.1016/j.stemcr. 2013.11.009)

Lombardi S, Honeth G, Ginestier C, Shinomiya I, Marlow R, Buchupalli B, Gazinska P, Brown J, Catchpole S, Liu S et al. 2014 Growth hormone is secreted by normal breast epithelium upon progesterone stimulation and increases proliferation of stem/progenitor cells. Stem Cell Reports 2 780-793. (doi:10.1016/j.stemcr.2014.05.005)

Lydon JP, DeMayo FJ, Funk CR, Mani SK, Hughes AR, Montgomery CA Jr, Shyamala G, Conneely OM \& O’Malley BW 1995 Mice lacking progesterone receptor exhibit pleiotropic reproductive abnormalities. Genes and Development 9 2266-2278. (doi:10.1101/gad.9.18.2266)

Lydon JP, Ge G, Kittrell FS, Medina D \& O'Malley BW 1999 Murine mammary gland carcinogenesis is critically dependent on progesterone receptor function. Cancer Research 59 4276-4284.

McClelland RA, Barrow D, Madden TA, Dutkowski CM, Pamment J, Knowlden JM, Gee JM \& Nicholson RI 2001 Enhanced epidermal growth factor receptor signaling in MCF7 breast cancer cells after longterm culture in the presence of the pure antiestrogen ICI 182,780 (Faslodex). Endocrinology 142 2776-2788.

Medina D 2004 Breast cancer: the protective effect of pregnancy. Clinical Cancer Research 10 380S-384S. (doi:10.1158/1078-0432.CCR-031211)

Miranda-Lorenzo I, Dorado J, Lonardo E, Alcala S, Serrano AG, ClausellTormos J, Cioffi M, Megias D, Zagorac S, Balic A et al. 2014 Intracellular autofluorescence: a biomarker for epithelial cancer stem cells. Nature Methods 11 1161-1169. (doi:10.1038/nmeth.3112)

Mokbel K 2002 The evolving role of aromatase inhibitors in breast cancer. International Journal of Clinical Oncology 7 279-283.

Morimoto K, Kim SJ, Tanei T, Shimazu K, Tanji Y, Taguchi T, Tamaki Y, Terada N \& Noguchi S 2009 Stem cell marker aldehyde dehydrogenase 1-positive breast cancers are characterized by negative estrogen receptor, positive human epidermal growth factor receptor type 2 , and high Ki67 expression. Cancer Science 100 1062-1068. (doi:10.1111/j. 1349-7006.2009.01151.x)

Mote PA, Bartow S, Tran N \& Clarke CL 2002 Loss of co-ordinate expression of progesterone receptors $\mathrm{A}$ and $\mathrm{B}$ is an early event in breast carcinogenesis. Breast Cancer Research and Treatment 72 163-172. (doi:10.1023/A:1014820500738)

Mulac-Jericevic B, Mullinax RA, DeMayo FJ, Lydon JP \& Conneely OM 2000 Subgroup of reproductive functions of progesterone mediated by progesterone receptor-B isoform. Science 289 1751-1754. (doi:10.1126/ science.289.5485.1751)

Mulac-Jericevic B, Lydon JP, DeMayo FJ \& Conneely OM 2003 Defective mammary gland morphogenesis in mice lacking the progesterone receptor B isoform. PNAS 100 9744-9749. (doi:10.1073/pnas. 1732707100)

Musgrove EA \& Sutherland RL 2009 Biological determinants of endocrine resistance in breast cancer. Nature Reviews. Cancer 9 631-643. (doi:10.1038/nrc2713)

Narod SA 2011 Hormone replacement therapy and the risk of breast cancer. Nature Reviews. Clinical Oncology 8 669-676. (doi:10.1038/nrclinonc. 2011.110)
Navarrete MA, Maier CM, Falzoni R, Quadros LG, Lima GR, Baracat EC \& Nazario AC 2005 Assessment of the proliferative, apoptotic and cellular renovation indices of the human mammary epithelium during the follicular and luteal phases of the menstrual cycle. Breast Cancer Research 7 R306-R313. (doi:10.1186/bcr994)

Palafox M, Ferrer I, Pellegrini P, Vila S, Hernandez-Ortega S, Urruticoechea A, Climent F, Soler MT, Munoz P, Vinals F et al. 2012 RANK induces epithelial-mesenchymal transition and stemness in human mammary epithelial cells and promotes tumorigenesis and metastasis. Cancer Research 72 2879-2888. (doi:10.1158/0008-5472.CAN-12-0044)

Patrawala L, Calhoun T, Schneider-Broussard R, Zhou J, Claypool K \& Tang DG 2005 Side population is enriched in tumorigenic, stem-like cancer cells, whereas $\mathrm{ABCG}^{+}$and $\mathrm{ABCG}^{-}$cancer cells are similarly tumorigenic. Cancer Research 65 6207-6219. (doi:10.1158/0008-5472. CAN-05-0592)

Pece S, Tosoni D, Confalonieri S, Mazzarol G, Vecchi M, Ronzoni S, Bernard L, Viale G, Pelicci PG \& Di Fiore PP 2010 Biological and molecular heterogeneity of breast cancers correlates with their cancer stem cell content. Cell 140 62-73. (doi:10.1016/j.cell.2009.12.007)

Perou CM, Sorlie T, Eisen MB, van de Rijn M, Jeffrey SS, Rees CA, Pollack JR, Ross DT, Johnsen H, Akslen LA et al. 2000 Molecular portraits of human breast tumours. Nature 406 747-752. (doi:10.1038/35021093)

Petersen OW, Hoyer PE \& van Deurs B 1987 Frequency and distribution of estrogen receptor-positive cells in normal, nonlactating human breast tissue. Cancer Research 47 5748-5751.

Phillips TM, McBride WH \& Pajonk F 2006 The response of CD24 $(-/$ low $) / \mathrm{CD} 44^{+}$breast cancer-initiating cells to radiation. Journal of the National Cancer Institute 98 1777-1785. (doi:10.1093/jnci/djj495)

Piva M, Domenici G, Iriondo O, Rabano M, Simões BM, Comaills V, Barredo I, Lopez-Ruiz JA, Zabalza I, Kypta R et al. 2014 Sox2 promotes tamoxifen resistance in breast cancer cells. EMBO Molecular Medicine 6 66-79. (doi:10.1002/emmm.201303411)

Ponti D, Costa A, Zaffaroni N, Pratesi G, Petrangolini G, Coradini D, Pilotti S, Pierotti MA \& Daidone MG 2005 Isolation and in vitro propagation of tumorigenic breast cancer cells with stem/progenitor cell properties. Cancer Research 65 5506-5511. (doi:10.1158/0008-5472. CAN-05-0626)

Poole AJ, Li Y, Kim Y, Lin SC, Lee WH \& Lee EY 2006 Prevention of Brca1mediated mammary tumorigenesis in mice by a progesterone antagonist. Science 314 1467-1470. (doi:10.1126/science.1130471)

Potten CS, Watson RJ, Williams GT, Tickle S, Roberts SA, Harris M \& Howell A 1988 The effect of age and menstrual cycle upon proliferative activity of the normal human breast. British Journal of Cancer $\mathbf{5 8}$ 163-170. (doi:10.1038/bjc.1988.185)

Rajkumar L, Guzman RC, Yang J, Thordarson G, Talamantes F \& Nandi S 2001 Short-term exposure to pregnancy levels of estrogen prevents mammary carcinogenesis. PNAS 98 11755-11759. (doi:10.1073/pnas. 201393798)

Reya T, Morrison SJ, Clarke MF \& Weissman IL 2001 Stem cells, cancer, and cancer stem cells. Nature 414 105-111. (doi:10.1038/35102167)

Richer JK, Jacobsen BM, Manning NG, Abel MG, Wolf DM \& Horwitz KB 2002 Differential gene regulation by the two progesterone receptor isoforms in human breast cancer cells. Journal of Biological Chemistry 277 5209-5218. (doi:10.1074/jbc.M110090200)

Russo J, Moral R, Balogh GA, Mailo D \& Russo IH 2005 The protective role of pregnancy in breast cancer. Breast Cancer Research 7 131-142. (doi:10.1186/bcr1029)

Sato T, Tran TH, Peck AR, Girondo MA, Liu C, Goodman CR, Neilson LM Freydin B, Chervoneva I, Hyslop T et al. 2014 Prolactin suppresses a progestin-induced CK5-positive cell population in luminal breast cancer through inhibition of progestin-driven BCL6 expression. Oncogene 33 2215-2224. (doi:10.1038/onc.2013.172)

Schramek D, Leibbrandt A, Sigl V, Kenner L, Pospisilik JA, Lee HJ, Hanada R, Joshi PA, Aliprantis A, Glimcher L et al. 2010 Osteoclast differentiation factor RANKL controls development of progestin-driven mammary cancer. Nature 468 98-102. (doi:10.1038/nature09387) 
Shiah YJ, Tharmapalan P, Casey AE, Joshi PA, McKee TD, Jackson HW, Beristain AG, Chan-Seng-Yue MA, Bader GD, Lydon JP et al. 2015 A progesterone-CXCR4 axis controls mammary progenitor cell fate in the adult gland. Stem Cell Reports 4 313-322. (doi:10.1016/j.stemcr. 2015.01.011)

Shiau AK, Barstad D, Loria PM, Cheng L, Kushner PJ, Agard DA \& Greene GL 1998 The structural basis of estrogen receptor/coactivator recognition and the antagonism of this interaction by tamoxifen. Cell 95 927-937. (doi:10.1016/S0092-8674(00)81717-1)

Simões BM \& Vivanco MD 2011 Cancer stem cells in the human mammary gland and regulation of their differentiation by estrogen. Future Oncology 7 995-1006. (doi:10.2217/fon.11.80)

Simões BM, Piva M, Iriondo O, Comaills V, Lopez-Ruiz JA, Zabalza I, Mieza JA, Acinas O \& Vivanco MD 2011 Effects of estrogen on the proportion of stem cells in the breast. Breast Cancer Research and Treatment 129 23-35. (doi:10.1007/s10549-010-1169-4)

Simões BM, O'Brien CS, Eyre R, Silva A, Yu L, Sarmiento-Castro A, Alferez D, Spence K, Santiago-Gómez A, Chemi F et al. 2015 Anti-estrogen resistance in human breast tumors is driven by JAG1-NOTCH4dependent cancer stem cell activity. Cell Reports 12 1968-1977. (doi:10.1016/j.celrep.2015.08.050)

Speirs V, Skliris GP, Burdall SE \& Carder PJ 2002 Distinct expression patterns of ER $\alpha$ and ER $\beta$ in normal human mammary gland. Journal of Clinical Pathology 55 371-374. (doi:10.1136/jcp.55.5.371)

Stylianou S, Clarke RB \& Brennan K 2006 Aberrant activation of notch signaling in human breast cancer. Cancer Research 66 1517-1525. (doi:10.1158/0008-5472.CAN-05-3054)

Thiery JP 2002 Epithelial-mesenchymal transitions in tumour progression. Nature Reviews. Cancer 2 442-454. (doi:10.1038/nrc822)

Turnbull AK, Arthur LM, Renshaw L, Larionov AA, Kay C, Dunbier AK, Thomas JS, Dowsett M, Sims AH \& Dixon JM 2015 Accurate prediction and validation of response to endocrine therapy in breast cancer. Journal of Clinical Oncology 33 2270-2278. (doi:10.1200/JCO.2014. 57.8963)

Turner NC, Ro J, Andre F, Loi S, Verma S, Iwata H, Harbeck N, Loibl S, Huang Bartlett C, Zhang K et al. 2015 Palbociclib in hormone-receptor-positive advanced breast cancer. New England Journal of Medicine 373 209-219. (doi:10.1056/NEJMoa1505270)

Visvader JE \& Lindeman GJ 2012 Cancer stem cells: current status and evolving complexities. Cell Stem Cell 10 717-728. (doi:10.1016/j.stem. 2012.05.007)

Wang Z, Zhang X, Shen P, Loggie BW, Chang Y \& Deuel TF 2005 Identification, cloning, and expression of human estrogen receptor$\alpha 36$, a novel variant of human estrogen receptor- $\alpha 66$. Biochemical and Biophysical Research Communications 336 1023-1027. (doi:10.1016/j. bbrc.2005.08.226)

Wang Z, Zhang X, Shen P, Loggie BW, Chang Y \& Deuel TF 2006 A variant of estrogen receptor- $\{\alpha\}, \mathrm{hER}-\{\alpha\} 36$ : transduction of estrogen- and antiestrogen-dependent membrane-initiated mitogenic signaling. PNAS 103 9063-9068. (doi:10.1073/pnas.0603339103)

Widschwendter M, Rosenthal AN, Philpott S, Rizzuto I, Fraser L, Hayward J, Intermaggio MP, Edlund CK, Ramus SJ, Gayther SA et al. 2013 The sex hormone system in carriers of BRCA1/2 mutations: a case-control study. Lancet. Oncology 14 1226-1232. (doi:10.1016/S14702045(13)70448-0)

Yager JD \& Davidson NE 2006 Estrogen carcinogenesis in breast cancer. New England Journal of Medicine 354 270-282. (doi:10.1056/ NEJMra050776)

Yamaji D, Na R, Feuermann Y, Pechhold S, Chen W, Robinson GW \& Hennighausen L 2009 Development of mammary luminal progenitor cells is controlled by the transcription factor STAT5A. Genes and Development 23 2382-2387. (doi:10.1101/gad.1840109)

Yang MH, Wu MZ, Chiou SH, Chen PM, Chang SY, Liu CJ, Teng SC \& Wu KJ 2008 Direct regulation of TWIST by HIF- $1 \alpha$ promotes metastasis. Nature Cell Biology 10 295-305. (doi:10.1038/ncb1691)

Yu F, Li J, Chen H, Fu J, Ray S, Huang S, Zheng H \& Ai W 2011 Kruppel-like factor 4 (KLF4) is required for maintenance of breast cancer stem cells and for cell migration and invasion. Oncogene 30 2161-2172. (doi:10.1038/onc.2010.591)

Zhang P, Andrianakos R, Yang Y, Liu C \& Lu W 2010 Kruppel-like factor 4 (Klf4) prevents embryonic stem (ES) cell differentiation by regulating Nanog gene expression. Journal of Biological Chemistry 285 9180-9189. (doi:10.1074/jbc.M109.077958)

Received in final form 11 September 2015

Accepted 15 September 2015

Made available online as an Accepted Preprint

16 September 2015
(C) 2015 Society for Endocrinology Printed in Great Britain 